\title{
Water-Rock Interaction Effect on Evolution of Total Hardness in Groundwater in Urban
}

\author{
Seyf-Laye Alfa-Sika Mande ${ }^{1,2,3, *}$, Mingzhu Liu ${ }^{1}$, Ibrahim Tchakala ${ }^{2}$, Honghan Chen ${ }^{1}$ \\ ${ }^{1}$ Beijing Key Laboratory of Water Resources \& Environmental Engineering, China University of Geosciences (Beijing), \\ Beijing 100083, P.R. China \\ ${ }^{2}$ Water Chemistry Laboratory, Faculty of Science, University of Lome, BP. 1515, Togo \\ ${ }^{3}$ Faculty of Science and Technology, University of Kara, BP. 404, Togo \\ *Corresponding author: seyf08@live.com
}

\begin{abstract}
Groundwater is the most important source of water supply in Beijing city. However, groundwater has undergone intensive total hardness pollution caused by water-rock interaction and by human activities. Analysis of monitoring data of 30 years shows that the high concentration of total hardness is relationship with carbonate mineral dissolution and cation exchange. But speciation calculations of two flow path using the hydrogeochemical modeling code PHREEQC indicated that the annual contribution of carbonate dissolution and cation exchange to concentration of $\mathrm{Ca}^{2+}$ and $\mathrm{Mg}^{2+}$ is less than $1 \mathrm{mg} \cdot \mathrm{L}^{-1}$, which was far less than that observed. The results illustrated that carbonate mineral dissolution and cation exchange in aquifers play a small role in the contribution of groundwater chemical evolution, and also imply other anthropogenic sources exist indirectly.
\end{abstract}

Keywords: water-Rock Interaction, hardness, groundwater, water supply, pollution

Cite This Article: Seyf-Laye Alfa-Sika Mande, Mingzhu Liu, Ibrahim Tchakala, and Honghan Chen, "Water-Rock Interaction Effect on Evolution of Total Hardness in Groundwater in Urban." American Journal of Water Resources, vol. 6, no. 2 (2018): 48-52. doi: 10.12691/ajwr-6-2-1.

\section{Introduction}

The study area is located in the upper and middle sections of the alluvial fan of the Yongding River, this includes several Beijing administrative divisions such as the Shijingshan District, Chaoyang District, Fengtai District and the piedmont region in Haidian District (Figure 1). In the western study area, the water quality was relatively good. The total hardness of the groundwater in the middle area has exceeded $450 \mathrm{mg} / \mathrm{L}$ from 1960 to the present, which according to Chinese national drinking water standards is not suitable for domestic use. The total hardness and concentrations of $\mathrm{NO}_{3}{ }^{-}, \mathrm{Cl}^{-}, \mathrm{SO}_{4}{ }^{2-}$, TDS, etc are generally higher in the northern and western regions of the confined aquifer. However the concentrations decrease with increasing groundwater depth. In some eastern parts of the alluvial fan, shallow aquifers with a depth in $0-40 \mathrm{~m}$, have higher concentration of total hardness and nitrate as nitrogen $\left(\mathrm{N}^{-\mathrm{NO}_{3}}{ }_{3}\right)^{\text {. }}$ Research has shown that the higher total hardness of groundwater in the Beijing urban areas are influenced by anthropogenic activities. Cation exchange of calcium, magnesium and ammonium control the hardness increment of groundwater in a continuous infiltration condition [1]. The contribution of total hardness from mineral dissolution is the secondary water rock interaction [2]. It is however difficult to distinguish $t$ and quantify the natural hydrogeochemical processes from human activities. Generally, the studies of water-rock interactions were adapted from hydrogeochemical methods. A few programs for hydrogeochemical processes such as NETPATH [3]. and PHREEQC [4]. have been used to model hydrochemical processes occurring along a flow path within an aquifer $[5,6,7,8,9]$.

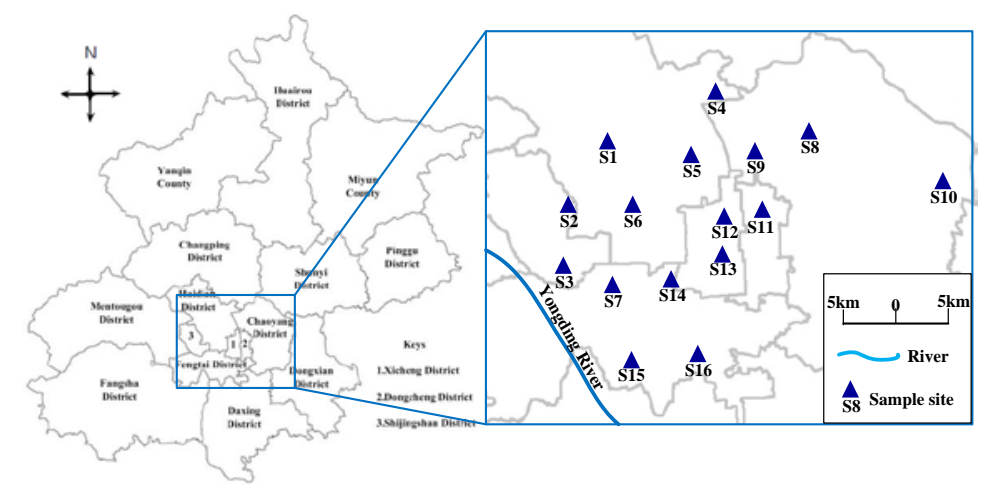

Figure 1. Area of study scheme with location of water sample in Beijing Administrative Region 
In this study, PHREEQC was used to simulate the impact of mineral dissolution and ion exchange which influence the evolution of total hardness in groundwater quality.

\section{Geology and Hydrogeology}

The study area is located in a semi-arid climatic zone and has an annual temperature of $11.7^{\circ} \mathrm{C}$. The mean annual precipitation was $610 \mathrm{~mm}$ from 1980 to 2005. The precipitation is dominated by the East Asian Monsoon between June and September and it accounts for about $85 \%$ of annual precipitation. Mean potential evaporation is $1826 \mathrm{~mm}$ from 1980 to 2005 [10].

The thickness of the Quaternary aquifers varies from 30 to $280 \mathrm{~m}$ in study area. Unconfined aquifers occur in the upper alluvial fan, they consist mainly of gravel and coarse sand with high hydraulic conductivity values of $200-500 \mathrm{~m} / \mathrm{d}$. In the middle of the alluvial fan, the Quaternary deposit with a thickness of $100-280 \mathrm{~m}$ is composed of coarse sand, sand and clay. This is divided into two or three aquifers with hydraulic conductivity values of $50-80 \mathrm{~m} / \mathrm{d}$.

The groundwater recharge in the study area comes from the lateral runoff of the western piedmont, precipitation, surface water infiltration, and recharge of irrigation water. The discharge comes from extraction, runoff downstream, and evaporation in some areas.

Before the 1960's, the groundwater was insignificantly affected due to urban anthropogenic activity, with the natural state flowing from west to east and south. However, since the 1970's, due to over-extraction, the groundwater levels have declined dramatically with an average rate of about $1 \mathrm{~m} / \mathrm{a}$. The average depth of groundwater level has fallen to over $30 \mathrm{~m}$.

\section{Hydrochemical Characteristics}

The area of study is located in the alluvial-fan of the

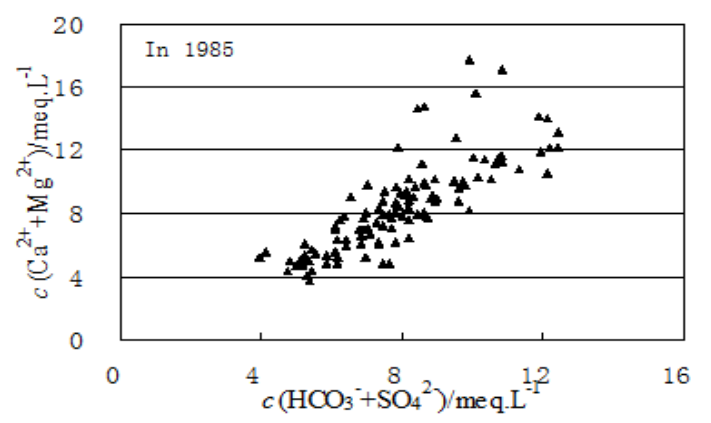

Yongding River, which has a large population density. The groundwater quality has been affected by a number of anthropogenic activities, including agriculture, domestic sewage, industrial wastewater and landfill leachate. According to the various characteristics of the ion concentrations in the groundwater and from natural groundwater to the anthropogenic groundwater, four stages can be identified as follows:

During the 1950s, the groundwater in the study area was essentially in its natural condition. Only the water quality of the unconfined aquifers and some shallow confined aquifers of the old central city was slightly affected by seepage wells and septic pits. At this time the groundwater chemical type was $\mathrm{HCO}_{3}-\mathrm{Ca} \bullet \mathrm{Mg}$. The areas, where the content of total hardness in groundwater exceeded $450 \mathrm{mg} / \mathrm{L}$, was nearly $42 \mathrm{~km}^{2}$ in the unconfined and shallow confined aquifers.

With increased urbanization from 1960 to 1970, population and industrial growth resulted in groundwater extraction increasing from $0.05 \times 108 \mathrm{~m}^{3} / \mathrm{a}$ to $10.8 \times 108 \mathrm{~m}^{3} / \mathrm{a}$, and the rate of sewage leakage also increased. Therefore, the groundwater quality deteriorated gradually. The total hardness increased from $220 \mathrm{mg} / \mathrm{L}$ to $300 \mathrm{mg} / \mathrm{L}$, and nitrate as nitrogen from $1 \mathrm{mg} / \mathrm{L}$ to $6 \mathrm{mg} / \mathrm{L}$ in the groundwater.

From 1980 to 1990, the total water demand in urban areas increased to $26.2 \times 108 \mathrm{~m}^{3} / \mathrm{a}$, and the discharge of wastewater increased to $7.82 \times 108 \mathrm{~m}^{3}$, which was 32 times the discharge of the early 1950's, as a result groundwater quality has deteriorated even more. Excluding total hardness (increased from $350 \mathrm{mg} / \mathrm{L}$ to 600 $\mathrm{mg} / \mathrm{L}$ ) and nitrate as nitrogen (increased from $8 \mathrm{mg} / \mathrm{L}$ to $24 \mathrm{mg} / \mathrm{L}$ ), the total dissolved solids(TDS) in groundwater has also increased from $500 \mathrm{mg} / \mathrm{L}$ to $900 \mathrm{mg} / \mathrm{L}$.

In the late 1990s, the total hardness and TDS tended to decrease, the hardness decreased from $680 \mathrm{mg} / \mathrm{L}$ to 500 $\mathrm{mg} / \mathrm{L}$, TDS from $1100 \mathrm{mg} / \mathrm{L}$ to $900 \mathrm{mg} / \mathrm{L}$.

From 1999, with lower precipitation and increasing groundwater extraction has resulted in a continuous decline of regional groundwater level. The total hardness of the groundwater also began to gradually increase again.

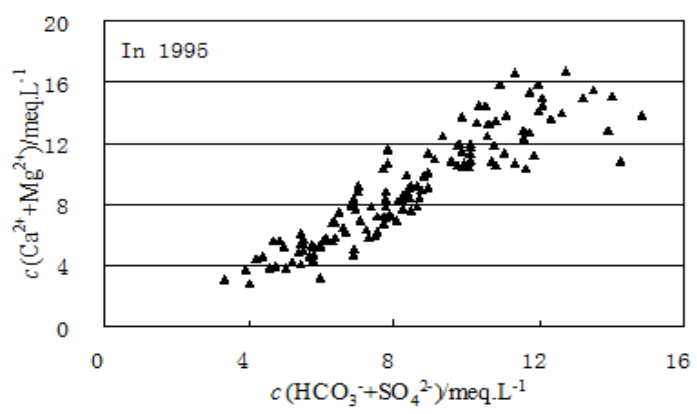

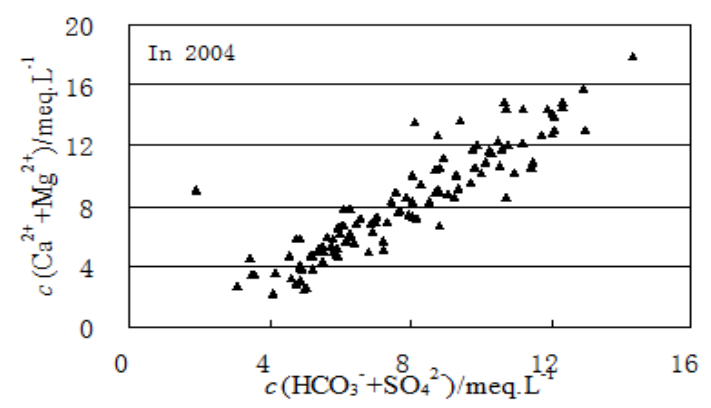

Figure 2. Scatter plot of c(Ca $+\mathrm{Mg})$ vs. $\mathrm{c}\left(\mathrm{HCO}_{3}+\mathrm{SO}_{4}\right)$ 


\section{Water-Rock Interaction of Evolution of Total Hardness}

\subsection{Mineral Dissolution}

The aquifer in the study area consists of mainly Quaternary sediments; therefore, $\mathrm{HCO}_{3}{ }^{-}, \mathrm{Ca}^{2+}$ and $\mathrm{Mg}^{2+}$ are likely from carbonate minerals or from calcium and magnesium mineral dissolution. Previous research [11-17] has shown that $\mathrm{c}\left(\mathrm{Ca}^{2+}+\mathrm{Mg}^{2+}\right) / \mathrm{c}\left(\mathrm{HCO}_{3}{ }^{-}+\mathrm{SO}_{4}{ }^{2-}\right)>>1$ which denotes carbonate dissolution, and $\mathrm{c}\left(\mathrm{Ca}^{2+}+\mathrm{Mg}^{2+}\right) / \mathrm{c}\left(\mathrm{HCO}_{3}{ }^{-}+\mathrm{SO}_{4}{ }^{2-}\right)$ $<1$ refers to silicate dissolution; if $\mathrm{c}\left(\mathrm{Ca}^{2+}+\mathrm{Mg}^{2+}\right)$ /c $\left(\mathrm{HCO}_{3}{ }^{-}+\mathrm{SO}_{4}{ }^{2-}\right) \approx 1$, then this implies a combination of both carbonate and silicate dissolution.

The collection of monitoring data from 1975 to 2004 shows that the values of $\mathrm{c}\left(\mathrm{Ca}^{2+}+\mathrm{Mg}^{2+}\right) / \mathrm{c}\left(\mathrm{HCO}_{3}{ }^{-}+\mathrm{SO}_{4}{ }^{2-}\right)$ of most of the observation points is ranges from 0.9 to 1.2 in the area of study. Because of the discontinuous collection, the monitoring data in 1975, 1985, 1995, 2004 was used to analyse the process of mineral dissolution. The scatter diagram (Figure 2) of $\mathrm{c}\left(\mathrm{Ca}^{2+}+\mathrm{Mg}^{2+}\right) / \mathrm{c}\left(\mathrm{HCO}_{3}{ }^{-}+\mathrm{SO}_{4}{ }^{2-}\right)$ shows that the source of $\mathrm{Ca}^{2+}, \mathrm{Mg}^{2+}$ and $\mathrm{HCO}_{3}{ }^{-}$originate more from carbonate mineral dissolution than silicate mineral. Therefore, $\mathrm{HCO}_{3}{ }^{-}$can be used as an indicator of the region's groundwater water-rock interaction. The high concentrations of $\mathrm{Ca}^{2+}, \mathrm{Mg}^{2+}$ and $\mathrm{HCO}_{3}{ }^{-}$reflect mineral dissolution and rock weathering processes in the study area.

\subsection{Ion Exchange}

As previously mentioned, the major sources of $\mathrm{Ca}^{2+}$ and $\mathrm{HCO}_{3}{ }^{-}$of the study area originate due to a carbonate mineral dissolution process. This process demonstrates that an increase in the concentration of $\mathrm{HCO}_{3}^{-}$should result in an increase in the concentration of $\mathrm{Ca} 2+$. However, if $\mathrm{Na} / \mathrm{Ca}$ exchange takes place, the concentration of $\mathrm{Ca}^{2+}$ will be lower, while the concentration of $\mathrm{Na}^{+}$will be higher. A common feature of $\mathrm{Ca} / \mathrm{Na}$ exchange is: when concentration of $\mathrm{HCO}_{3}{ }^{-}$increases, $\mathrm{Ca}^{2+}$ will decrease, and $\mathrm{Na}+$ will increase. This type of region is the typical region of $\mathrm{Ca} / \mathrm{Na}$ exchange. In the study area, concentrations of $\mathrm{HCO}_{3}{ }^{-}$and $\mathrm{Na}+$ increased, while the concentration of $\mathrm{Ca}^{2+}$ decreased. This shows that $\mathrm{Ca} / \mathrm{Na}$ ion exchange occurred in this area.

\section{Water-Rock Interaction of Evolution of Total Hardness}

\subsection{Flow Paths of Modeling}

The simulated path located in the area where the flow field of groundwater is relatively stable. The flow path of modeling in groundwater should be located in relatively stable flow regime area. According to the groundwater flow regime from 2001 to 2005 in area of study, two flow paths was used to model. Path I-I' is located in the single aquifer area and Path II-II' is located in the multi-aquifer area (Figure 3). The simulation time is from 2000 to 2005. The flow rate of path I-I' is $1.5 \mathrm{~m} \cdot \mathrm{d}^{-1}$, and the length of the path is $2737.5 \mathrm{~m}$. The flow rate of path II-II' is $0.5 \mathrm{~m} / \mathrm{d}$ and the length of the path is $912.5 \mathrm{~m}$

\subsection{Selection of Phases}

According to monitoring data of water quality in the area of study, nine ions with respect to $\mathrm{pH}, \mathrm{HCO}_{3}{ }^{-}, \mathrm{Cl}^{-}$, $\mathrm{SO}_{4}{ }^{2-}, \mathrm{NO}_{3}{ }^{-}, \mathrm{Ca}^{2+}, \mathrm{Mg}^{2+}, \mathrm{K}^{+}, \mathrm{Na}^{+}$are selected to simulate the phases. The monitoring data for the year 2000 was used as the initial concentration of the model (Table 1), and solution 0 , solution 1 , and solution 2 represent initial concentrations of cells in their respective modeling paths. The initial ion concentrations in solution 0 , solution 1 and solution 2 were obtained from the concentration contour map, as well as the observed concentration in each section.

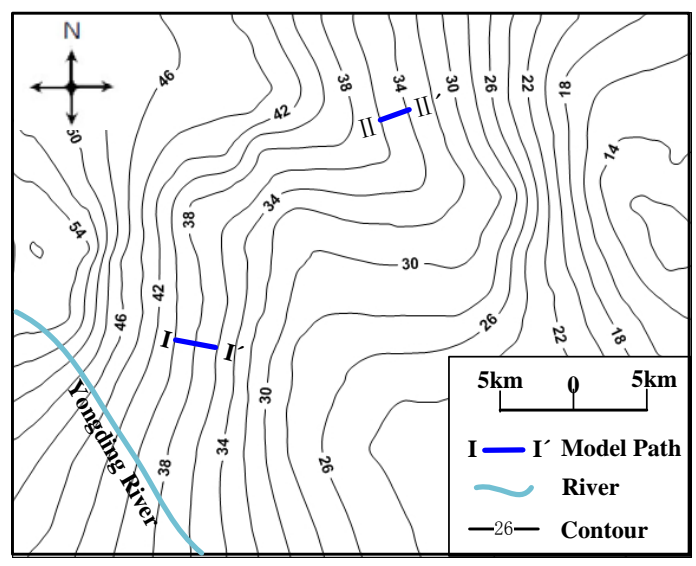

Figure 3. 1D water-rock interaction modeling paths in area of study

Table 1. Initial concentrations of each component in model

\begin{tabular}{|l|c|c|c|c|c|c|}
\hline \multirow{2}{*}{ Components } & \multicolumn{6}{|c|}{ Initial concentration $\left(\mathrm{mg}^{-\mathrm{L}^{-1}}\right)$} \\
\cline { 2 - 7 } & \multicolumn{2}{|c|}{ Solution 0 } & \multicolumn{2}{|c|}{ Solution 1 } & \multicolumn{2}{c|}{ Solution 2 } \\
\cline { 2 - 7 } & I-I’ & II-II & I-I’ & II-II’ & I-I’ & II-II \\
\hline $\mathrm{pH}$ & 7.6 & 7.8 & 7.7 & 7.8 & 7.7 & 7.8 \\
\hline $\mathrm{HCO}_{3}{ }^{-}$ & 299.0 & 24.1 & 296.7 & 247.7 & 292.2 & 249.2 \\
\hline $\mathrm{Cl}^{-}$ & 114.0 & 13.0 & 129.2 & 13.5 & 159.7 & 14.5 \\
\hline $\mathrm{SO}_{4}{ }^{2-}$ & 139.0 & 56.8 & 140.5 & 56.85 & 143.5 & 570.0 \\
\hline $\mathrm{NO}_{3}{ }^{-}$ & 19.2 & 6.1 & 17.1 & 6.45 & 12.9 & 7.1 \\
\hline $\mathrm{Ca}^{2+}$ & 88.2 & 56.5 & 86.1 & 56.8 & 82.0 & 57.6 \\
\hline $\mathrm{Mg}^{2+}$ & 35.9 & 27.1 & 37.4 & 27.3 & 40.4 & 27.8 \\
\hline $\mathrm{K}^{+}$ & 9.13 & 1.5 & 9.4 & 1.48 & 9.9 & 1.5 \\
\hline $\mathrm{Na}^{+}$ & 82.1 & 13.2 & 84.6 & 13.27 & 89.5 & 13.4 \\
\hline
\end{tabular}

\section{Calculation of Saturation Index}

Table 2. Calculations of saturation index of minerals for water samples

\begin{tabular}{|c|c|c|c|c|c|c|c|c|}
\hline \multirow{2}{*}{ Minerals } & \multicolumn{10}{|c|}{ Saturation Index } \\
\cline { 2 - 10 } & S1 & S2 & S3 & S4 & S5 & S6 & S7 & S8 \\
\hline Dolomite & 0.37 & 0.46 & 0.40 & 0.48 & 0.55 & 0.41 & 0.40 & 0.12 \\
\hline Calcite & 0.34 & 0.41 & 0.40 & 0.32 & 0.41 & 0.34 & 0.36 & 0.22 \\
\hline \multirow{2}{*}{ Minerals } & \multicolumn{10}{|c|}{ Saturation Index } \\
\cline { 2 - 10 } & S9 & S10 & S11 & S12 & S13 & S14 & S15 & S16 \\
\hline Dolomite & -0.19 & 0.75 & 0.35 & 0.37 & 0.51 & 0.15 & 0.59 & 0.69 \\
\hline Calcite & 0.22 & 0.29 & 0.25 & 0.34 & 0.37 & 0.24 & 0.40 & 0.48 \\
\hline
\end{tabular}

The locations of saturation index (SI) calculations are shown in Figure 1. The calculation results of SI are listed in Table 2. It shows that the SI of calcite and dolomite of this area is generally greater than 0 . Therefore, Ca2+, $\mathrm{Mg} 2+$ and HCO3- in the groundwater in most areas of study, are in an oversaturated state with respect to calcite and dolomite. 
Table 3. Results of calculation and observed values of path I-I' and II-II' unit: mg/L

\begin{tabular}{|c|c|c|c|c|c|c|c|}
\hline \multirow{2}{*}{$\mathrm{P}$} & \multirow{2}{*}{ C } & \multicolumn{2}{|c|}{ Mineral dissolution +migration } & \multicolumn{2}{|c|}{ Mineral dissolution + ion-exchange+ migration } & \multirow{2}{*}{ OV } & \multirow{2}{*}{ Va.OV } \\
\hline & & SV & Va. SV & SV & Va. SV & & \\
\hline \multirow{3}{*}{ I-I' } & $\mathrm{HCO}_{3}{ }^{-}$ & 295.8 & -3.21 & 295.85 & -3.15 & 368 & 69 \\
\hline & $\mathrm{Ca}^{2+}$ & 88.1 & -0.12 & 88.08 & -0.12 & 126 & 37.8 \\
\hline & $\mathrm{Mg}^{2+}$ & 35.9 & 0.004 & 35.90 & 0.004 & 46 & 10.1 \\
\hline \multirow{3}{*}{ II-II' } & $\mathrm{HCO}_{3}{ }^{-}$ & 247.2 & 0.23 & 247.29 & 0.29 & 283 & 36. \\
\hline & $\mathrm{Ca}^{2+}$ & 60.6 & 4.14 & 60.64 & 4.14 & 78 & 21.5 \\
\hline & $\mathrm{Mg}^{2+}$ & 24.9 & -2.24 & 24.84 & -2.26 & 33 & 5.9 \\
\hline
\end{tabular}

P: Path; C: Component; SV: Simulated values; Va.SV: Variation of Simulated values; OV: Observed values; Va.OV: Variation of Observed values.

\section{Results and Discussion}

For the analyses of water-rock interaction on the total hardness in groundwater, two scenarios of mineral dissolution and ion-exchange + mineral dissolution were used in the simulation. The results are shown in Table 3. The simulated results of the transport model for calcite and dolomite dissolution show that the concentration variation of $\mathrm{Ca}^{2+}, \mathrm{Mg}^{2+}$ and $\mathrm{HCO}_{3}{ }^{-}$is very small. The max variation of the $\mathrm{I}^{-\mathrm{I}^{\prime}}$ path is $\mathrm{HCO}_{3}{ }^{-}$, and the maximum value of variation is only $-3.21 \mathrm{mg} \cdot \mathrm{L}-1$ in five years; path II-II' is $\mathrm{Ca}^{2+}$, and the concentration increased $4.14 \mathrm{mg} \cdot \mathrm{L}-1$ in five years. The contribution of mineral dissolution + ion-exchange to the concentration of $\mathrm{Ca}^{2+}, \mathrm{Mg}^{2+}$ and $\mathrm{HCO}_{3}{ }^{-}$etc., is less than $1 \mathrm{mg} \cdot \mathrm{L}^{-1} \cdot \mathrm{yr}^{-1}$.

Comparison of simulated values and measured values shows that the concentration of $\mathrm{Ca}^{2+}, \mathrm{Mg}^{2+}$ and $\mathrm{HCO}_{3}{ }^{-}$was larger than the measured values of these of point I and II in 2000. In path I-I', the concentration of $\mathrm{Ca}^{2+}, \mathrm{Mg}^{2+}$ and $\mathrm{HCO}_{3}{ }^{-}$has increased nearly $0.50-1.00 \mathrm{mmol} \cdot \mathrm{L}^{-1}$; and nearly $0.25-0.50 \mathrm{mmol} \cdot \mathrm{L}-1$ in path II-II'. This shows that although $\mathrm{Ca}^{2+}, \mathrm{Mg}^{2+}$ and $\mathrm{HCO}_{3}^{-}$in groundwater results from calcite and dolomite dissolution, mineral dissolution and ion-exchange contribute little to the concentration of $\mathrm{Ca}^{2+}, \mathrm{Mg}^{2+}$ and $\mathrm{HCO}_{3}{ }^{-}$in the groundwater. This would imply that the increase of total hardness, likely originated from upstream of the aquifer or from solute infiltration in the vadose zone.

\section{Conclusion}

The four stages were identified according to the various characteristics of the ion concentrations in the groundwater and from natural groundwater to the anthropogenic groundwater. The main water-rock interactions for groundwater total hardness in the study area include mineral dissolution processes and cation exchange. However, the concentration variation of $\mathrm{HCO}_{3}{ }^{-}$was only $-0.64 \mathrm{mg} \cdot \mathrm{L}^{-1} \cdot \mathrm{yr}^{-1}$, the concentration of $\mathrm{Ca}^{2+}$ increased $0.82 \mathrm{mg} \cdot \mathrm{L}^{-1} \cdot \mathrm{yr}^{-1}$. The contribution of mineral dissolution + ion-exchange to the concentration of $\mathrm{Ca}^{2+}, \mathrm{Mg}^{2+}$ and $\mathrm{HCO}_{3}{ }^{-}$is less than $1 \mathrm{mg} \cdot \mathrm{L}^{-1}$ annually, less than the observed values. In path I-I', the concentration of $\mathrm{Ca}^{2+}, \mathrm{Mg}^{2+}$ and $\mathrm{HCO}_{3}{ }^{-}$increased approximately $0.5-1.0 \mathrm{mmol} \cdot \mathrm{L}^{-1}$, and nearly $0.25-0.5 \mathrm{mmol} \cdot \mathrm{L}^{-1}$ in path II-II'. These results indicate that other sources exist besides the natural hydrogeochemical processess, and probably originated upstream of the aquifer or from solute infiltration in the vadose zone.

\section{Acknowledgements}

This research was supported by the studies of safety evaluation and pollution prevention technology and demonstration for groundwater resources in Beijing (D07050601510000) and Sate Science and Technology Major Project for Water Pollution Controls and Treatment (2009ZX07424).

\section{References}

[1] Wang Dongsheng., Shen Zhaoli., Zhong Zuoxin., Affects of nitrogen transformation of hardness increment of groundwater, Geosciences 1998, 12, 431-436.

[2] CHENG Donghui., CHEN Honghan.. A study of indicators of anthropogenic influence and water rock interaction in groundwater system in the urban region of Beijin, Hydrogeology \& Engineering Geology 2007, 5, 37-42.

[3] Plummer LN., Prestemon EC., Parkhurst DL.An interactive code (NETPATH) for modeling net geochemical reactions along a flow path, version 2.0. USGS Water-Resources Investigation Report, 1994, 94-4169.

[4] D. L. Parkhust., C. Appelo.,. Use's guide to PHREEQC (VERSION 2)-a computer program for speciation, batch-reaction, one-dimensional transport, and inverse geochemical calculations. USGS, Water Resource Investigations Report, 1999, 312-332.

[5] Lopez-Chicano M., Ouamama M., Vallejos A., Pulido-Bosch.,. Factors which determine the hydrogeochemical behavior of karstic springs: a case study from the Betic Cordilleras, Spain. Applied Geochemistry 2001, 16, 1179-1192.

[6] Larsen F., Owen R., Dahlin T., Mangeya P., Barmen G., A preliminary analysis of the groundwater recharge to the Karoo formations, mid-Zambezi basin, Zimbabwe. Physics and Chemistry of the Earth 2002, 7,765-772.

[7] Guler C., Thyne GD., Hydrologic and geologic factors controlling surface and groundwater chemistry in Indian Wells Owens-Valley area, southeastern California, USA. Hydrology 2004, 285, 177-198.

[8] Guo YH., Wang J., Lu CH., Liu SF., Zhong ZH. Chemical characteristics of groundwater and water-rock: modeling of the Yemaquan preselected area for China's high level radioactive waste repository. Earth Science Frontier 2005, 12,117-123.

[9] N. Subba Rao, Geochemistry of groundwater in parts of Guntur district, Andhra Pradesh, India. Environmental Geology 2002, 41, 552-562.

[10] R Stephen Fisher.,William F Mullican. Hydrochemical evolution of sodium-sulfate and sodium-chloride groundwater beneath the northern chihuahuan desert, tran-pecos, Texas, USA. Hydrogeology Journal 1997, 5, 4-16.

[11] E. Lakshmanan., R. Kannan., M. Senthil Kumar. Major ion chemistry and identification of hydrogeochemical processes of ground water in a part of Kancheepuram district, Tamil Nadu, India. Environmental Geosciences 2003, 10, 157-166.

[12] N. Rajmohan., L. Elango. Identification and evolution of hydrogeochemical processes in the groundwater environment in an area of the Palar and Cheyyar river basin, southern Indian. Environmental Geology 2004, 46, 47-61. 
[13] N. Abu-Jaber., M. Ismail. Hydrogeochemical modeling of the shallow groundwater in the northern Jordan valley. Environmental Geology 2003, 44, 391-399.

[14] Susan X Meng., J Barry Maynard. Use of statistical analysis to formulate conceptual models of geochemical behavior: water chemical data from the Botucatu aquifer in Sao Paulo state, Brazil. Journal of Hydrology 2001, 250, 78-97.
[15] Zhou Xun., Yao Jinmei., Zhang Hua., Li Rui., Xu Fang. Modeling of water-rock interactions in an aquitard of sandy clay in the coastal area near Beihai, China. Environmental Geology 2008, 56, 183-188.

[16] R. Umar., A. Absar. Chemical characteristics of groundwater in parts of the Gambhir river basin, Bharatpur district, Rajasthan, India. Environmental Geology 2003, 44, 535-544. 